\title{
Association of Osteocalcin and Abdominal Aortic Calcification in Older Women: The Study of Osteoporotic Fractures
}

\author{
Benjamin D. Parker • Douglas C. Bauer • \\ Kristine E. Ensrud • Joachim H. Ix
}

Received: 14 October 2009/Accepted: 23 December 2009/Published online: 23 January 2010

(C) The Author(s) 2010. This article is published with open access at Springerlink.com

\begin{abstract}
Osteocalcin (OC) is produced by osteoblasts and vascular smooth muscle cells. In animal models, serum OC levels are strongly correlated with vascular calcium content, however, the association of OC with vascular calcification in humans is uncertain. The Study of Osteoporotic Fractures (SOF) enrolled community-living women, age $\geq 65$ years. The present study included a subsample of 363 randomly selected SOF participants. Serum total OC was measured by ELISA, and abdominal aortic calcification (AAC) was evaluated on lateral lumbar radiographs. We examined the cross-sectional association between serum OC and AAC. The mean serum OC level
\end{abstract}

B. D. Parker · J. H. Ix ( $\square)$

Division of Nephrology and Hypertension, Department of Medicine, University of California, San Diego, San Diego, CA 92093, USA

e-mail: joeix@ucsd.edu

B. D. Parker · J. H. Ix

Veterans Affairs San Diego Healthcare System, 3350 La Jolla

Village Drive, Mail Code 111-H, San Diego, CA 92161, USA

D. C. Bauer

Departments of Medicine, Epidemiology, and Biostatistics, University of California, San Francisco, San Francisco,

CA 94143, USA

K. E. Ensrud

Veterans Affairs Medical Center, University of Minnesota, Minneapolis, MN, USA

\section{K. E. Ensrud}

Division of Epidemiology, Department of Medicine, University of Minnesota, Minneapolis, MN, USA

\section{J. H. Ix}

Division of Prevention, Department of Family and Preventive Medicine, University of California, La Jolla, CA 92093, USA was $24 \pm 11 \mathrm{ng} / \mathrm{ml}$ and $\mathrm{AAC}$ was present in 188 subjects (52\%). We observed no association of OC and AAC in either unadjusted or adjusted analyses. For example, each standard deviation higher OC level was associated with an odds ratio $(\mathrm{OR})$ for AAC prevalence (AAC score $>0$ ) near unity $(\mathrm{OR}=1.06 ; 95 \% \mathrm{CI}, 0.82-1.36)$ in models adjusted for CVD risk factors. Further adjustment for intact parathyroid hormone, bone-specific alkaline phosphatase, 25hydroxyvitamin $\mathrm{D}$, and hip and spine bone mineral density did not materially change the results $(\mathrm{OR}=1.22 ; 95 \% \mathrm{CI}$, $0.86-1.75)$. Similarly, higher OC levels were not associated with severity of AAC $(P=0.87)$. In conclusion, among community-living older women, serum OC is not associated with AAC. These findings suggest that serum OC levels may more closely reflect bone formation than vascular calcification in humans.

Keywords Osteocalcin - Vascular calcification . Cardiovascular disease $\cdot$ Aortic calcification

Cardiovascular disease (CVD) is the leading cause of death in older women [1], and traditional risk factors are less strongly associated with CVD events in women compared to men [2-5]. Prevalent vascular calcification has demonstrated utility in predicting CVD events in healthy community-living populations [6]. Previously thought to reflect an inevitable consequence of aging, recent studies demonstrate that vascular calcification is actively regulated, and several novel regulatory proteins have been identified [7]. One such protein is osteocalcin (OC) [8].

OC (a.k.a. bone gla protein) is traditionally considered a marker of osteoblast activity [9, 10], as it is produced in osteoblasts and is associated with high bone turnover and decreased bone mineral density (BMD) in a variety of 
clinical settings [11-13]. However, OC is also produced by calcifying vascular smooth muscle cells. In rodent models, serum OC levels are strongly associated with vascular calcium content, and treatment with bisphosphonates decreases vascular calcification and simultaneously lowers serum OC levels [14]. In pathologic studies in humans, OC levels are higher in calcified atherosclerotic plaques and calcified cardiac valves than in noncalcified vasculature [15]. These data suggest that higher serum OC levels may be useful as a marker of vascular calcium deposition and severity in humans. However, the association of serum OC levels and vascular calcification and CVD events has not been extensively studied, and the existing data are conflicting.

To that end, we evaluated the association between $\mathrm{OC}$ levels with abdominal aortic calcification (AAC) among a well-characterized cohort of older women who participated in the Study of Osteoporotic Fractures (SOF). We hypothesized that higher OC levels would be associated with a greater prevalent and severity of AAC, independent of traditional CVD risk factors, kidney function, or BMD.

\section{Methods}

\section{Study Participants}

The SOF is a multicenter observational study designed to identify risk factors for osteoporotic fractures in postmenopausal women. Methods have been described previously [16]. In brief, 9704 community-dwelling women aged $\geq 65$ years were recruited from population-based listings in Baltimore, Maryland; Minneapolis, Minnesota; the Monongahela Valley, Pennsylvania; and Portland, Oregon. Recruitment involved mailings to women on populationbased lists (voter registration, driver's license, and health maintenance organization lists). Women with bilateral hip replacements or who were unable to walk without assistance were excluded. African-American women were initially excluded because of their low incidence of hip fracture. The institutional review boards at the four clinical sites and the coordinating center approved the study protocol. All participants provided informed consent.

From 1986 to 1988, baseline examinations were performed, which included physical examination, health status questionnaires, dietary history, medical history, lateral lumbar radiographs, and collection of blood specimens. A sample of 400 women was selected at random for serum OC measurement. Of these, 3 subjects were excluded due to missing $\mathrm{OC}$ measurements and 34 were excluded for missing or technically uninterpretable lumbar radiographs for evaluation of AAC, resulting in a final analytic sample of 363 women for this analysis.
Osteocalcin

A detailed description of $\mathrm{OC}$ measurement has been reported previously [17]. Briefly, OC was measured in serum that had been stored at $-190^{\circ} \mathrm{C}$ at the Biomedical Research Institute (Rockville, MD). Total OC was measured with a human-specific immunoradiometric assay (ELSA-OSTEO; CIS BioInternational, Baglos/Ceze, France), which recognizes a large N-terminal midfragment in addition to the intact molecule. Intra- and interassay coefficients of variation were $<4$ and $<6 \%$, respectively [17]. All assays were performed in 1994 and 1995, 7-8 years after initial serum collection.

\section{Abdominal Aortic Calcification}

Lateral lumbar radiographs were taken with a tube-to-film distance of $101.6 \mathrm{~cm}$, centered at the third lumbar vertebrate (L3). From these, ACC scores [18] were determined by grading the severity of calcification in the abdominal aorta between the L1 and the L4 lumbar vertebrae. The radiodensity of the aortic wall was assessed at each vertebral segment, and calcific deposits were regarded as present if densities were visible in an area parallel to the lumbar spine and anterior to the lower part of the spine in the usual anatomic location of the abdominal aorta. Densities overlapping the vertebrae were deemed to represent AAC only if they extended from or formed a clear pattern with those of the lower part of the aorta. Calcific densities were graded on a scale of 0 to 3 at each lumbar vertebral segment. A score of 0 denoted no aortic calcific deposits; 1, small scattered calcific deposits, filling less than one-third of the longitudinal wall of the aorta; 2 , calcification involving between one-third and two-thirds of the longitudinal wall of the aorta; and 3, calcification involving two-thirds or more of the longitudinal wall of the aorta. A separate score was determined for the anterior and posterior aorta, and the values were summed across the four vertebrae, resulting in an AAC score that could range from 0 to 24 points. All radiographs were assessed by a single reader who was blinded to all clinical data. Intraobserver variability of 30 randomly selected radiographs showed 93\% agreement between the first and the second readings, for a $\kappa$ value of 0.87 (lower bound of CI: 0.54) [19].

\section{Other Measurements}

Participants were weighed wearing light clothes and no shoes on a balance-beam scale and height was measured using a standard held-expiration technique with a wallmounted Harpenden stadiometer. Body mass index (BMI) was calculated $\left(\mathrm{kg} / \mathrm{m}^{2}\right)$. Blood pressure measurements 
were made in the supine position in the right brachial artery using an appropriately sized cuff by sphygmomanometer (Baum Co., New York). Hypertension was defined as systolic blood pressure $>140 \mathrm{mmHg}$, diastolic blood pressure $>90 \mathrm{mmHg}$, or use of diuretics. Sensitivity analysis, where hypertension was defined only based on systolic and diastolic blood pressure criteria yielded identical results in the final analyses. Use of other antihypertensive medications was not recorded at the baseline study visit. Questionnaires [20, 21] provided age; history of diabetes, stroke, osteoporosis, and fractures after age 50; cigarette use; use of select medications (calcium supplements, vitamin D supplements, estrogen, steroids, and diuretics); and years since menopause. Dietary calcium, protein, and phosphorus intake was estimated with a validated food frequency questionnaire, developed from the Second National Health and Nutrition Examination Survey [22].

Blood specimens collected at the baseline visit were used to measure creatinine, C-reactive protein, 25-hydroxyvitamin D, and intact parathyroid hormone (PTH) levels. Serum creatinine was measured with the use of an automated analyzer and was combined with age, gender, and race to estimate glomerular filtration rate (eGFR) by the four-variable Modification of Diet in Renal Disease Study (MDRD) equation [23]. Chronic kidney disease was defined as an eGFR $<60 \mathrm{ml} / \mathrm{min} / 1.73 \mathrm{~m}^{2}$ [24]. C-Reactive protein level was measured by a high-sensitivity enzymelinked immunosorbent assay (ELISA) based on purified protein and polyclonal anti-C-reactive-protein antibodies (Calbiochem, La Jolla, CA) [25]. Intact PTH (interassay variability, $8.5 \%$ ) was measured by immunoradiometric assay (IRMA), and serum 25-hydroxyvitamin D (interassay variability, $15 \%$ ) was measured by radioimmunoassay at the University of California, San Francisco, Calciotropic Hormone Reference Laboratory [26]. Serum bone-specific alkaline phosphatase (interassay variability, <9\%) was measured with an IRMA using two monoclonal antibodies against the human bone isoenzyme (Ostate; Hybriteck, Inc., San Diego, CA) [27].

Hip and spine BMD were not evaluated at the baseline study visit but were measured at the first follow-up visit among $83 \%(N=303)$ of participants, an average of 3.8 years (range, 3.3-5.1 years) after their baseline visit. Detailed descriptions of BMD are given elsewhere [28]. In brief, BMD of the proximal femur and spine was measured in the anteroposterior projection visit using a Hologic QDR 1000 scanner (Hologic, Inc., Waltham, MD). Coefficients of variation were 1.2 and $1.5 \%$, respectively. All measurements were made on the right except in the rare instances when subjects reported a stroke, fracture, or severe injury involving the right limb, in which case the left side was used.
Statistical Analysis

A priori, we elected to evaluate serum OC levels on a continuous scale (per standard deviation [SD] increase) as our primary predictor variable. However, for descriptive statistics, we categorized participants by tertiles of serum OC levels and compared baseline characteristics using analysis of variance (ANOVA) or the Kruskal-Wallis test for continuous variables and the chi-square test or Fisher's exact test for categorical variables, as appropriate. Tertiles were chosen to provide a cursory evaluation of the linearity of associations, while simultaneously maximizing the number of subjects in each category.

We categorized AAC as present (AAC score $>0$ ) or absent as the primary outcome variable. Multivariable logistic regression evaluated the association of $\mathrm{OC}$ with AAC prevalence. The initial model was age adjusted. The second model was adjusted for established CVD risk factors (age, BMI, systolic and diastolic blood pressure, diabetes, hypertension, smoking, estrogen use, eGFR, and Creactive protein). The final model adjusted for all variables in the second model, with additional adjustment for hormone regulators of bone metabolism (intact PTH, bonespecific alkaline phosphatase, 25-hydroxyvitamin D) and hip and spine BMD. Among participants with prevalent AAC (AAC score $>0$ ), the relationship between OC and AAC severity [(ln)AAC score] was evaluated by linear regression in companion analyses. Model adjustment followed the identical sequence outlined above. This relationship is expressed as a percentage difference in AAC score. The distribution of OC levels was evaluated by graphical methods and was approximately normally distributed, with a few high-value outliers. We evaluate OC levels on a continuous scale, per SD increase. In sensitivity analysis, exclusion of the few high outliers resulted in similar findings, so data presented retain the outliers within the analysis. All analyses were performed using Stata Statistical Software, version 9.2 (College Station, TX).

\section{Results}

Among the 363 study participants, the mean age was $72 \pm 5$ years, $65 \%$ had hypertension, and $9 \%$ had diabetes mellitus. OC was approximately normally distributed across the study sample, with a mean \pm SD of $24 \pm 11 \mathrm{ng} /$ $\mathrm{ml}$ (Fig. 1). AAC was present in 188 subjects (52\%). Among these, AAC scores were positively skewed, with a median score of 4.5 (interquartile range, 2.0-8.0).

Compared to subjects in the lowest OC tertile, those with higher OC levels were less likely to be taking calcium supplements or estrogen replacement and had lower C-reactive protein, higher intact PTH and bone-specific 
Fig. 1 Distribution of serum osteocalcin levels among older women

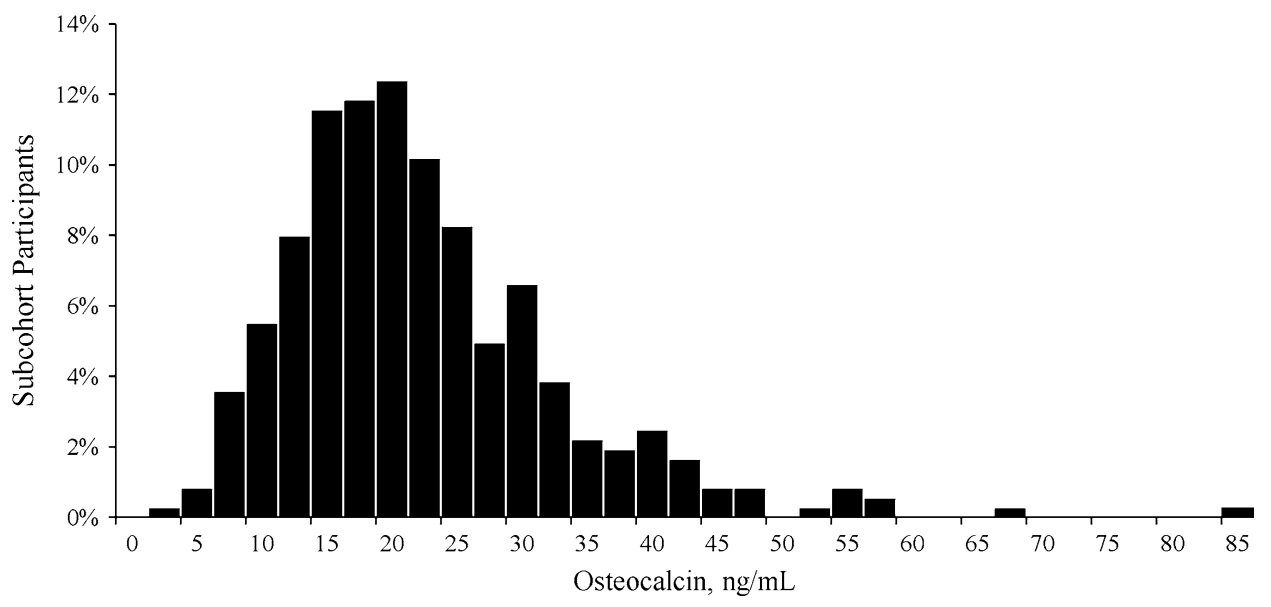

alkaline phosphatase levels, lower 25-hydroxyvitamin D levels, and lower hip and spine BMD measurements (Table 1). Subjects in either the high or the low OC tertile were more likely to have smoked than subjects with intermediate OC levels.

After adjustment for age, the association of OC levels and prevalent AAC was near unity (Table 2). Adjustment for CVD risk factors, markers of mineral metabolism, and BMD had little effect on this association. Findings were similar when evaluating the association of OC with AAC severity (Table 3). Low 25-hydroxyvitamin D (<30 ng/ $\mathrm{ml}$ ) was present in $70 \%$ of women and there was no significant association between $\mathrm{OC}$ and AAC when women were grouped by 25-hydroxyvitamin $\mathrm{D}$ status ( $P$ for interaction $=0.41)$. Roughly half of the women had intact PTH levels $>30 \mathrm{pg} / \mathrm{ml}$ and results were similar among persons with intact PTH levels above or below this level $(P$ for interaction $=0.85$ ).

\section{Discussion}

We found no evidence of an association between serum OC levels and AAC prevalence or severity among communityliving older women. The association remained near unity despite adjustment for CVD risk factors, estrogen use, kidney function, 25-hydroxyvitamin $\mathrm{D}$, intact parathyroid hormone, bone-specific alkaline phosphatase, and BMD. Serum OC levels may have limited utility as a marker of AAC in humans.

Prior studies evaluating the association of OC with vascular calcification and CVD have been conflicting. A recent study among 328 persons with diabetes from Japan demonstrated that higher OC levels were associated with decreased vascular stiffness and lower carotid intimal medial thickness in men but not women [29]. This finding is intriguing not only because of the gender differences, but also because vascular calcification is strongly linked with both vascular stiffness and atherosclerosis in humans [30, 31], and because higher OC levels are associated with vascular calcification in animal models. Thus the directions of association observed in this study are opposite to that observed in experimental animals. In contrast, FahrleitnerPammer et al. [32] followed 135 subjects with CKD for 4 years, 35 of whom experienced CVD events during follow-up. Baseline OC levels were higher in subjects who had CVD events in unadjusted analysis, but the association was not statistically significant in multivariable models. To our knowledge, only two prior studies have evaluated the association of serum OC levels and AAC [33, 34]. Both studies were relatively small, and neither adjusted for traditional CVD risk factors, kidney function, or BMD. In one, higher OC trended toward higher prevalence of AAC [33], whereas higher OC trended toward lower prevalence of AAC in the other study [34], although the associations were not significant in either analysis. One possible explanation is the use of different OC assays (due to differing specificities for OC fragments, accumulation of fragments with kidney dysfunction, and degradation of intact OC with storage). However, using an alternative assay, the data presented here confirm the absence of an association of $\mathrm{OC}$ with AAC prevalence and extend these data by demonstrating that $\mathrm{OC}$ levels are also not associated with AAC severity, and that the results remain similar despite adjustment for traditional CVD risk factors, kidney function, and markers of bone turnover and BMD.

The absence of an association of OC with AAC may, however, make OC a more useful marker of bone turnover without competing influences of vascular calcification as both processes frequently coexist in older persons [19, 3537]. Prior in vitro and animal studies demonstrated that OC was associated with vascular calcification, but the data presented here suggest that such relationships are not easily detected with serum OC levels in humans. While it might be expected that serum OC levels would be higher in individuals with increased vascular calcification, other 
Table 1 Participant characteristics by osteocalcin tertile

\begin{tabular}{|c|c|c|c|c|}
\hline & \multicolumn{3}{|c|}{ Osteocalcin, ng/ml } & \multirow[t]{2}{*}{$P$ value } \\
\hline & $\begin{array}{c}\text { Tertile } 1 \\
(<18.8 ; n=121)\end{array}$ & $\begin{array}{c}\text { Tertile 2 } \\
(18.8-25.8 ; n=121)\end{array}$ & $\begin{array}{c}\text { Tertile } 3 \\
(>25.8 ; n=121)\end{array}$ & \\
\hline Age, years & $72(5 \%)$ & $72(5 \%)$ & $72(5 \%)$ & 0.39 \\
\hline \multicolumn{5}{|l|}{ Medical history } \\
\hline Diabetes, No. & $15(12 \%)$ & $11(9 \%)$ & $7(6 \%)$ & 0.20 \\
\hline Chronic kidney disease ${ }^{\mathrm{a}}$, No. & $35(29 \%)$ & $32(27 \%)$ & $34(28 \%)$ & 0.92 \\
\hline Hypertension, No. & $81(67 \%)$ & $85(70 \%)$ & $71(59 \%)$ & 0.15 \\
\hline History of heart failure, No. & $3(3 \%)$ & $3(3 \%)$ & $5(5 \%)$ & 0.75 \\
\hline History of myocardial infarction, No. & $9(9 \%)$ & $6(6 \%)$ & $7(7 \%)$ & 0.72 \\
\hline History of stroke, No. & $3(3 \%)$ & $1(1 \%)$ & $2(2 \%)$ & 0.60 \\
\hline Osteoporosis or vertebral fracture, No. & $24(20 \%)$ & $22(18 \%)$ & $12(10 \%)$ & 0.09 \\
\hline Years since menopause & $23(7)$ & $23(9)$ & $25(8)$ & 0.08 \\
\hline History of ever smoking, No. & $57(48 \%)$ & $36(30 \%)$ & $49(41 \%)$ & 0.02 \\
\hline Pack years ${ }^{\mathrm{b}}$ for those who smoked & $28(23)$ & $27(20)$ & $26(24)$ & 0.96 \\
\hline \multicolumn{5}{|l|}{ Current medication use } \\
\hline Calcium supplements, No. & $77(64 \%)$ & $66(55 \%)$ & $52(43 \%)$ & 0.005 \\
\hline Vitamin D, No. & $58(48 \%)$ & $53(48 \%)$ & $48(40 \%)$ & 0.43 \\
\hline Estrogen, No. & $27(22 \%)$ & $5(4 \%)$ & $1(1 \%)$ & $<0.001$ \\
\hline Steroids use, No. & $3(2 \%)$ & $2(2 \%)$ & $0(0 \%)$ & 0.24 \\
\hline Diuretics, No. & $41(34 \%)$ & $40(33 \%)$ & $31(26 \%)$ & 0.31 \\
\hline \multicolumn{5}{|l|}{ Measurements } \\
\hline Body mass index, $\mathrm{kg} / \mathrm{m}^{2}$ & $27(5)$ & $27(5)$ & $26(4)$ & 0.23 \\
\hline Systolic blood pressure, $\mathrm{mmHg}$ & $143(20)$ & $145(22)$ & $140(22)$ & 0.24 \\
\hline Diastolic blood pressure, $\mathrm{mmHg}$ & $76(9)$ & $78(9)$ & $77(11)$ & 0.35 \\
\hline C-reactive protein, median $\mu \mathrm{g} / \mathrm{dl}$ (IQR) & $2.1(1.3-3.6)$ & $1.7(1.0-3.0)$ & $1.5(0.8-2.5)$ & 0.001 \\
\hline $\mathrm{eGFR},{ }^{\mathrm{c}} \mathrm{ml} / \mathrm{min} / 1.73 \mathrm{~m}^{2}$ & 70 (14) & $72(17)$ & $69(15)$ & 0.30 \\
\hline Serum calcium, mg/dl & $9.7(0.5)$ & $9.7(0.4)$ & $9.7(0.5)$ & 0.70 \\
\hline iPTH, median pg/ml (IQR) & $28(20-37)$ & $30(22-39)$ & $33(26-45)$ & 0.003 \\
\hline Bone-specific alk phos, median ng/ml (IQR) & $9.6(7.8-11.8)$ & $11.6(9.6-14.0)$ & $15.0(11.8-20.0)$ & $<0.001$ \\
\hline $25(\mathrm{OH})$ vitamin $\mathrm{D}, \mathrm{ng} / \mathrm{ml}$ & $27(11)$ & $27(12)$ & $24(9)$ & 0.03 \\
\hline Hip bone mineral density, $\mathrm{g} / \mathrm{cm}^{2}$ & $0.80(0.13)$ & $0.76(0.11)$ & $0.74(0.13)$ & $<0.001$ \\
\hline Spine bone mineral density, $\mathrm{g} / \mathrm{cm}^{2}$ & $0.90(0.17)$ & $0.85(0.13)$ & $0.83(0.16)$ & 0.02 \\
\hline Dietary calcium intake, median g/week (IQR) & $4.3(3.1-6.1)$ & $4.3(2.6-6.0)$ & $4.1(2.7-6.4)$ & 0.76 \\
\hline Dietary phosphorus intake, g/week & $6.7(3.0)$ & $6.6(3.1)$ & $6.6(2.7)$ & 0.98 \\
\hline Dietary protein intake, $\mathrm{g} /$ week & $345(126)$ & $347(140)$ & $343(127)$ & 0.98 \\
\hline
\end{tabular}

alk phos Alkaline phosphatase, eGFR estimated glomerular filtration rate, $i P T H$ intact parathyroid hormone, IQR interquartile range, $\mathrm{OH}$ hydroxylated. Data are presented as mean (SD) unless specified otherwise

${ }^{\text {a }}$ Chronic kidney disease: eGFR $<60 \mathrm{ml} / \mathrm{min} / 1.73 \mathrm{~m}^{2}$

b Pack years $=$ number of years smoking $\times$ (number of cigarettes per day /20)

${ }^{c}$ Calculated using the Modification of Diet in Renal Disease (MDRD) Study equation: $186 \times(\mathrm{Scr})^{-1.154} \times(\text { Age })^{-0.203} \times 0.742$ for non-African-American females

coexisting factors may abrogate any detectable changes in OC levels. For instance, the major source of circulating OC is likely from bone-resident osteoblasts [10, 38], so any contribution of $\mathrm{OC}$ to the circulating pool from vascular smooth muscle cells or myofibroblasts may be too small in comparison to be reliably detected by measurement at one point in time in serum.
Other factors such as vitamin $\mathrm{K}$ intake and warfarin use are potentially important determinants of OC activity. Vitamin K-dependent carboxylation of OC glutamate residues (a process inhibited by warfarin) enables OC to bind hydroxyapatite. Vitamin $\mathrm{K}$ intake and warfarin use were not recorded in this study, so it remains possible that associations may have differed in individuals with vitamin 
Table 2 Association of osteocalcin (per SD increase) with prevalent abdominal aortic calcification

\begin{tabular}{llll}
\hline & Odds ratio & $95 \%$ CI & $P$ value \\
\hline Age adjusted & 0.99 & $0.80-1.23$ & 0.96 \\
${\text { Multivariate model } 1^{\mathrm{a}}}^{\mathrm{a}}$ & 1.06 & $0.82-1.36$ & 0.67 \\
Multivariate model $^{\mathrm{b}}$ & 1.22 & $0.86-1.75$ & 0.26 \\
\hline
\end{tabular}

${ }^{a}$ Adjusted for age, body mass index, systolic and diastolic blood pressure, diabetes, hypertension, smoking history, estimated glomerular filtration rate, C-reactive protein, and estrogen use

b Adjusted for multivariate model 1+ intact parathyroid hormone, bone-specific alkaline phosphatase, and 25-hydroxyvitamin D; hip and spine bone mineral density

Table 3 Association of osteocalcin (per SD increase) with abdominal aortic calcification (AAC) severity $(N=188)$

\begin{tabular}{llll}
\hline & $\begin{array}{l}\text { Percentage change } \\
\text { in AAC severity }\end{array}$ & $95 \%$ CI & $P$ value \\
\hline Age adjusted & -6 & -16 to $5 \%$ & 0.29 \\
Multivariate model $1^{\mathrm{a}}$ & -7 & -17 to $5 \%$ & 0.25 \\
Multivariate model $2^{\mathrm{b}}$ & -1 & -17 to $17 \%$ & 0.87 \\
\hline
\end{tabular}

${ }^{a}$ Adjusted for age, body mass index, systolic and diastolic blood pressure, diabetes, hypertension, smoking history, estimated glomerular filtration rate, C-reactive protein, and estrogen use

b Adjusted for multivariate model $1+$ intact parathyroid hormone, bone-specific alkaline phosphatase, and 25-hydroxyvitamin D; hip and spine bone mineral density

${ }^{c}$ Coefficients of regression $(\mathrm{CR})$ are exponentiated $\left(e^{\mathrm{CR}}\right)$ so as to represent a percentage change in aortic calcification severity score per $\mathrm{SD}$ increase in serum osteocalcin

$\mathrm{K}$ deficiency or in warfarin users. This question requires future study.

Strengths of this study include the availability of OC, AAC, traditional CVD risk factors, mineral metabolism, and BMD measurements concurrently among a well-characterized cohort of older women. The study also has important limitations. First, while more than half of participants had prevalent AAC, improving the statistical power, the study sample was relatively small. We cannot exclude the possibility that an association of OC with AAC was missed due to chance or that other imaging modalities may have been more sensitive. Results should be interpreted within the confines of the $95 \%$ confidence intervals. Second, all participants were older women and were almost exclusively Caucasian. Results may not generalize to younger persons, men, or other race/ethnicities. Two factors which affect $\mathrm{OC}$ activation (vitamin K status and warfarin use) were not measured. The assay for OC used in our study does not discriminate between carboxylated and uncarboxylated OC, and measurement of these specific forms of OC may provide different results. Finally, our analysis is limited by its cross-sectional design, so temporal direction of associations could not be assessed.
In conclusion, in community-living older women, serum OC levels are not associated with either AAC prevalence or severity. It is likely that serum total OC more strongly reflects bone osteoblast activity than vascular smooth muscle cell calcification. These data do not support the use of OC as a marker of vascular calcification in humans.

Acknowledgments This study was supported by Grants T32 HL007261 (B.D.P), R21 HL091217 (J.H.I.), and R21 HL09121701A2S1 (B.D.P.) through the National Heart Lung and Blood Institute; and an American Heart Association Fellow-to-Faculty transition grant (J.H.I.). The Study of Osteoporotic Fractures (SOF) is supported by National Institutes of Health funding. The National Institute on Aging (NIA) provides support under the following Grant numbers: AG05407, AR35582, AG05394, AR35584, AR35583, R01 AG005407, R01 AG027576-22, 2 R01 AG005394-22A1, and 2 R01 AG027574-22A1. The funding organizations had no role in the design and conduct of the study; collection, management, analysis, and interpretation of the data; or preparation, review, or approval of the manuscript.

Open Access This article is distributed under the terms of the Creative Commons Attribution Noncommercial License which permits any noncommercial use, distribution, and reproduction in any medium, provided the original author(s) and source are credited.

\section{References}

1. Rosamond W, Flegal K, Furie K, Go A, Greenlund K, Haase N, Hailpern SM, Ho M, Howard V, Kissela B, Kittner S, LloydJones D, McDermott M, Meigs J, Moy C, Nichol G, O’Donnell C, Roger V, Sorlie P, Steinberger J, Thom T, Wilson M, Hong Y (2008) Heart disease and stroke statistics-2008 update: a report from the American Heart Association Statistics Committee and Stroke Statistics Subcommittee. Circulation 117:e25-e146

2. Braunwald E (1997) Shattuck lecture-cardiovascular medicine at the turn of the millennium: triumphs, concerns, and opportunities. N Engl J Med 337:1360-1369

3. Manolio TA, Pearson TA, Wenger NK, Barrett-Connor E, Payne GH, Harlan WR (1992) Cholesterol and heart disease in older persons and women. Review of an NHLBI workshop. Ann Epidemiol 2:161-176

4. Rimm EB, Stampfer MJ, Ascherio A, Giovannucci E, Colditz GA, Willett WC (1993) Vitamin E consumption and the risk of coronary heart disease in men. N Engl J Med 328:1450-1456

5. Stampfer MJ, Hennekens CH, Manson JE, Colditz GA, Rosner B, Willett WC (1993) Vitamin E consumption and the risk of coronary disease in women. N Engl J Med 328:1444-1449

6. Detrano R, Guerci AD, Carr JJ, Bild DE, Burke G, Folsom AR, Liu K, Shea S, Szklo M, Bluemke DA, O'Leary DH, Tracy R, Watson K, Wong ND, Kronmal RA (2008) Coronary calcium as a predictor of coronary events in four racial or ethnic groups. $\mathrm{N}$ Engl J Med 358:1336-1345

7. Giachelli CM (2004) Vascular calcification mechanisms. J Am Soc Nephrol 15:2959-2964

8. Hruska KA, Mathew S, Saab G (2005) Bone morphogenetic proteins in vascular calcification. Circ Res 97:105-114

9. Price PA (1985) Vitamin K-dependent formation of bone Gla protein (osteocalcin) and its function. Vitam Horm 42:65-108

10. Price PA, Williamson MK, Lothringer JW (1981) Origin of the vitamin $\mathrm{K}$-dependent bone protein found in plasma and its clearance by kidney and bone. J Biol Chem 256:12760-12766 
11. Brown JP, Delmas PD, Malaval L, Edouard C, Chapuy MC, Meunier PJ (1984) Serum bone Gla-protein: a specific marker for bone formation in postmenopausal osteoporosis. Lancet 1:10911093

12. Malluche HH, Faugere MC, Fanti P, Price PA (1984) Plasma levels of bone Gla-protein reflect bone formation in patients on chronic maintenance dialysis. Kidney Int 26:869-874

13. Minisola S, Rosso R, Romagnoli E, DE E, Manfredi G, Damiani C, De Antoni F, Mazzuoli G (1997) Serum osteocalcin and bone mineral density at various skeletal sites: a study performed with three different assays. J Lab Clin Med 129:422-429

14. Price PA, Roublick AM, Williamson MK (2006) Artery calcification in uremic rats is increased by a low protein diet and prevented by treatment with ibandronate. Kidney Int 70:1577-1583

15. Levy RJ, Gundberg C, Scheinman R (1983) The identification of the vitamin K-dependent bone protein osteocalcin as one of the gamma-carboxyglutamic acid containing proteins present in calcified atherosclerotic plaque and mineralized heart valves. Atherosclerosis 46:49-56

16. Cummings SR, Black DM, Nevitt MC, Browner WS, Cauley JA, Genant HK, Mascioli SR, Scott JC, Seeley DG, Steiger P et al (1990) Appendicular bone density and age predict hip fracture in women. The Study of Osteoporotic Fractures Research Group. JAMA 263:665-668

17. Garnero P, Grimaux M, Demiaux B, Preaudat C, Seguin P, Delmas PD (1992) Measurement of serum osteocalcin with a human-specific two-site immunoradiometric assay. J Bone Miner Res 7:1389-1398

18. Kauppila LI, Polak JF, Cupples LA, Hannan MT, Kiel DP, Wilson PW (1997) New indices to classify location, severity and progression of calcific lesions in the abdominal aorta: a 25 -year follow-up study. Atherosclerosis 132:245-250

19. Vogt MT, San Valentin R, Forrest KY, Nevitt MC, Cauley JA (1997) Bone mineral density and aortic calcification: the Study of Osteoporotic Fractures. J Am Geriatr Soc 45:140-145

20. Bauer DC, Browner WS, Cauley JA, Orwoll ES, Scott JC, Black DM, Tao JL, Cummings SR (1993) Factors associated with appendicular bone mass in older women. The Study of Osteoporotic Fractures Research Group. Ann Intern Med 118:657-665

21. Cummings SR, Nevitt MC, Browner WS, Stone K, Fox KM, Ensrud KE, Cauley J, Black D, Vogt TM (1995) Risk factors for hip fracture in white women. Study of Osteoporotic Fractures Research Group. N Engl J Med 332:767-773

22. Block G, Hartman AM, Dresser CM, Carroll MD, Gannon J, Gardner L (1986) A data-based approach to diet questionnaire design and testing. Am J Epidemiol 124:453-469

23. Levey AS, Coresh J, Greene T, Stevens LA, Zhang YL, Hendriksen S, Kusek JW, Van Lente F (2006) Using standardized serum creatinine values in the modification of diet in renal disease study equation for estimating glomerular filtration rate. Ann Intern Med 145:247-254

24. National Kidney Foundation (2002) K/DOQI clinical practice guidelines for chronic kidney disease: evaluation, classification, and stratification. Am J Kidney Dis 39:S1-S266
25. Macy EM, Hayes TE, Tracy RP (1997) Variability in the measurement of C-reactive protein in healthy subjects: implications for reference intervals and epidemiological applications. Clin Chem 43:52-58

26. Cummings SR, Browner WS, Bauer D, Stone K, Ensrud K, Jamal S, Ettinger B (1998) Endogenous hormones and the risk of hip and vertebral fractures among older women. Study of Osteoporotic Fractures Research Group. N Engl J Med 339:733-738

27. Garnero P, Delmas PD (1993) Assessment of the serum levels of bone alkaline phosphatase with a new immunoradiometric assay in patients with metabolic bone disease. J Clin Endocrinol Metab 77:1046-1053

28. Steiger P, Cummings SR, Black DM, Spencer NE, Genant HK (1992) Age-related decrements in bone mineral density in women over 65. J Bone Miner Res 7:625-632

29. Kanazawa I, Yamaguchi T, Yamamoto M, Yamauchi M, Kurioka S, Yano S, Sugimoto T (2009) Serum osteocalcin level is associated with glucose metabolism and atherosclerosis parameters in type 2 diabetes mellitus. J Clin Endocrinol Metab 94:45-49

30. Oei HH, Vliegenthart R, Hak AE, Iglesias del Sol A, Hofman A, Oudkerk M, Witteman JC (2002) The association between coronary calcification assessed by electron beam computed tomography and measures of extracoronary atherosclerosis: the Rotterdam Coronary Calcification Study. J Am Coll Cardiol 39:1745-1751

31. Guerin AP, London GM, Marchais SJ, Metivier F (2000) Arterial stiffening and vascular calcifications in end-stage renal disease. Nephrol Dial Transplant 15:1014-1021

32. Fahrleitner-Pammer A, Herberth J, Browning SR, ObermayerPietsch B, Wirnsberger G, Holzer H, Dobnig H, Malluche HH (2008) Bone markers predict cardiovascular events in chronic kidney disease. J Bone Miner Res 23:1850-1858

33. Jie KS, Bots ML, Vermeer C, Witteman JC, Grobbee DE (1995) Vitamin $\mathrm{K}$ intake and osteocalcin levels in women with and without aortic atherosclerosis: a population-based study. Atherosclerosis 116:117-123

34. Iba K, Takada J, Yamashita T (2004) The serum level of bonespecific alkaline phosphatase activity is associated with aortic calcification in osteoporosis patients. J Bone Miner Metab 22:594-596

35. Boukhris R, Becker KL (1972) Calcification of the aorta and osteoporosis. A roentgenographic study. JAMA 219:1307-1311

36. Hak AE, Pols HA, van Hemert AM, Hofman A, Witteman JC (2000) Progression of aortic calcification is associated with metacarpal bone loss during menopause: a population-based longitudinal study. Arterioscler Thromb Vasc Biol 20:1926-1931

37. Tanko LB, Christiansen C, Cox DA, Geiger MJ, McNabb MA, Cummings SR (2005) Relationship between osteoporosis and cardiovascular disease in postmenopausal women. J Bone Miner Res 20:1912-1920

38. Fraser JD, Price PA (1988) Lung, heart, and kidney express high levels of mRNA for the vitamin K-dependent matrix Gla protein. Implications for the possible functions of matrix Gla protein and for the tissue distribution of the gamma-carboxylase. J Biol Chem 263:11033-11036 